\title{
Feeding Habits of the Cichlid Chromidotilapia guntheri (Sauvage, 1882) in Some Hydrosystems of Ivory Coast.
}

\author{
Charles Koffi BOUSSOU (Corresponding author) \\ Department of Environment, University Jean Lorougnon Guédé \\ POB 150 Daloa, Ivory Coast \\ E-mail: bkofficharles@live.fr \\ Gustave N'guessan ALIKO \\ Department of Environment, University Jean Lorougnon Guédé \\ POB 150 Daloa, Ivory Coast \\ E-mail: gustavealiko@yahoo.fr
}

\begin{abstract}
Mexmin Koffi KONAN
Department of Sciences and Environment Managment, University Nangui Abrogoua,

02 BP 801 Abidjan 02, Ivory Coast

E-mail: konanmexmin@hotmail.fr
\end{abstract}

\section{Felix Koffi KONAN}

Department of Environment, University Jean Lorougnon Guédé

POB 150 Daloa, Ivory Coast

E-mail: konanfelix@yahoo.fr

Received: December 30, 2017 Accepted: January 15, 2018 Published: January 20, 2018

doi:10.5296/ast.v6i1.12511 URL: https://doi.org/10.5296/ast.v6i1.12511 


\section{Abstract}

The feeding habit of Chromidotilapia guntheri was investigated in seven hydrosystems of Ivory Coast. The contents of 156 non-empty stomachs were examined from specimens caught in the rivers Soumié, Eholié, Noé, Ehania and Banco, the Bea rill and the Kpoda lake. Diets composition, feeding strategy and trophic niche width were analyzed among hydrosystems. Stomach content analysis indicated that $C$. guntheri feeds preferentially on plants and insects debris and secondarily, it consumed insects' larvae, nymphs and adults in all habitats. This species would be an omnivorous with a detritivorous tendency. As feeding strategy, it practices a generalist strategy even if some individuals displayed specialization intentions on insects at different stages of metamorphosis. Investigations on ontogenetic shift revealed that juveniles and adults of $C$. guntheri consume substantially the same types of prey with varying amounts depending on the size of the fish. However there is a significant decrease in the proportions of gastropods and oligochaetes ingested when growing.

Keywords: Chromidotilapia guntheri, feeding habits, Ivory Coast.

\section{Introduction}

Chromidotilapia guntheri is a freshwater cichlid widely distributed in West Africa. It is known from the coastal basins from the River St. John in Liberia to the Cross in (Nigeria/Cameroon) (Paugy et al., 2003). C. guntheri exists in the Niger Basin (Benue included). Despite its widespread occurrence, $C$. guntheri has never been adequately studied. Studies on this species are scarce and available information is on the species distribution in natural habitats (Teugels et al., 1988; Lévêque et al., 1991; Vivien, 1991; Paugy et al., 1994; Konan et al., 2006) and morphometry (Boussou et al., 2010). Although it is not an economically important species, it does form an important component of the subsistence catch in Ivorian coastal rivers (Gourène et al., 1999; Da Costa et al., 2000; Konan et al., 2006). Boussou et al. (2010) investigated its reproductive biology in hydrosystems of south and east of Ivory Coast and showed that $C$. guntheri is a multiple (fractional) spawner and breeds all year round with little fluctuation in spawning intensity. However, spawning activities were more intensive in August and September. The estimated mean standard length at first maturity did not differ significantly between rivers. Diet is a basic determinant of organism biology, being related with most of the ecological attributes (Hughes, 1993). Diet has been associated with morphology (Winemiller, 1991), physiology (McNab, 2002), behaviour (Ward et al., 2004), population abundances (Brown et al., 2004) and dynamics (Berryman, 1999), community structure (Arim et al., 2007) and even ecosystem processes (Thébault \& Loreau, 2006). As a consequence, knowing species trophic behavior represents a central step in order to advance in understanding its natural history. Wootton (1990) also states that feeding is one of the most important functions of an organism, since growth, development and reproduction are the result of the quantity and quality of the food that a species ingests.

The present study deals with the feeding habits of Chromidotilapia guntheri in some hydrosystems of eastern Ivory Coast on the basis of stomach content analysis. The specific goals are to determine diets composition and variations, trophic niche widths, feeding 
strategies among habitats and assess ontogenetic changes in diet composition.

\section{Materials and Methods}

\subsection{Study Area and Sampling Sites}

Five coastal rivers (Banco, Soumié, Eholié, Ehania and Noé), a rill (Bea) and one man-made lake were taken in account in this study (figure 1). They belong to the Western Guinean ichthyoregion, Eburnéo-Ghanaian sector and are located in lowland rainforest (Daget \& Iltis, 1965). Noé River $\left(05^{\circ} 19^{\prime}-05^{\circ} 35^{\prime} \mathrm{N}\right.$ and $\left.02 \circ 55^{\prime}-02 \circ 47^{\prime} \mathrm{W}\right)$ and Ehania River $\left(05 \circ 17^{\prime}-\right.$ $05 \circ 43^{\prime} \mathrm{N}$ and $\left.02 \circ 46^{\prime}-03 \circ 03^{\prime} \mathrm{W}\right)$ are tributaries of Tanoé River. The Soumié River $\left(05 \circ 23^{\prime}\right.$ $05^{\circ} 39^{\prime} \mathrm{N}$ and $\left.03 \circ 15^{\prime}-03 \circ 29^{\prime} \mathrm{W}\right)$ is a tributary of the Bia River. Eholié River $\left(05^{\circ} 21^{\prime}\right.$ $05{ }^{\circ} 36^{\prime} \mathrm{N}$ and $\left.03 \circ 10^{\prime}-02 \circ 59^{\prime} \mathrm{W}\right)$ runs into Aby lagoon. Bea Rill $\left(5^{\circ} 39\right.$ 'N and $\left.3^{\circ} 45^{\prime} \mathrm{W}\right)$ is a watershed head small stream and a secondary tributary of Comoé river. Its average bed width is barely over $1 \mathrm{~m}$. Banco River achieves its full course in a protected forest within Abidjan city, the Banco National Park and runs into Ebrié Lagoon. Kpoda Lake $\left(8^{\circ} 05\right.$ 'N and $2^{\circ} 51^{\prime}$ $\mathrm{W})$ is a hydro-agricultural reservoir built on an upper secondary tributary of Comoé River.

\subsection{Fish Sampling}

Fishes were sampled during eight surveys from July 2003 to March 2005 according to the climatic seasons of study area. Four surveys were conducted during each season (dry and rainy). The sampling sites covered a river section of approximately $1.5 \mathrm{~km}$ in length (i.e. reach scale), in order to sample a sufficient degree of habitat heterogeneity. Fishes were collected with two sets of eight gillnets (mesh sizes 12, 15, 17, 22, 25, 30, 40 and $45 \mathrm{~mm}$ ). In Banco River and Kpoda Lake, fish were captured during three campaigns between February and March of 2009 with gill nets. In Bea Rill, specimens of C. guntheri were obtained from waterside residents fishing with hooks not baited, between August and September 2009. Fish specimens were identified according to the keys of Paugy et al. (2003). Each specimen was measured (standard length and total length) to the nearest millimeter and weighed to the nearest gram in situ. Fishes were then preserved in formalin $5 \%$ for later laboratory observations.

\subsection{Laboratory Work}

Stomachs were removed and preserved in 5\% formalin. Then all food items were removed for examination under a stereomicroscope at 40x magnification. Each insect item in the stomach was identified to the lowest possible taxonomic level according to Tachet et al. (2003) and Dejoux et al. (1981) insects' identification keys. Or when necessary, assigned to different food categories such as adult insects, Insects pupae, insects larvae, insects pieces, plant fragments, mud (silt), sand, Bivalves, gastropods, fish scales, fruits, fish eggs and unidentified debris (difficult to identify as animal or plant debris). As a proxy for the relative abundance of each prey item, food items were spread along a metric paper attached to a Petri dish, and then the number of millimeter squares occupied by each item was recorded.

Gut contents were analyzed according to the method of frequency of occurrence, the volumetric analysis index and food items importance index following the procedure of 
Lima-Junior \& Goitein (2001).

The Frequency of Occurrence, expressed as a percentage, is the number of times that a food item occurs in the stomachs analyzed, divided by the total number of stomachs analyzed containing prey:

Occurrence Frequency of prey $i(\%)=100 \times \frac{\sum \text { Stomachs with prey } i}{\sum \text { Stomachs with prey }}$

The Volumetric Analysis Index indicates the relative abundance of a particular item found in the stomach samples. Its calculation is based on points ascribed to distinct food items after a simple visual inspection of the stomach's food contents. 


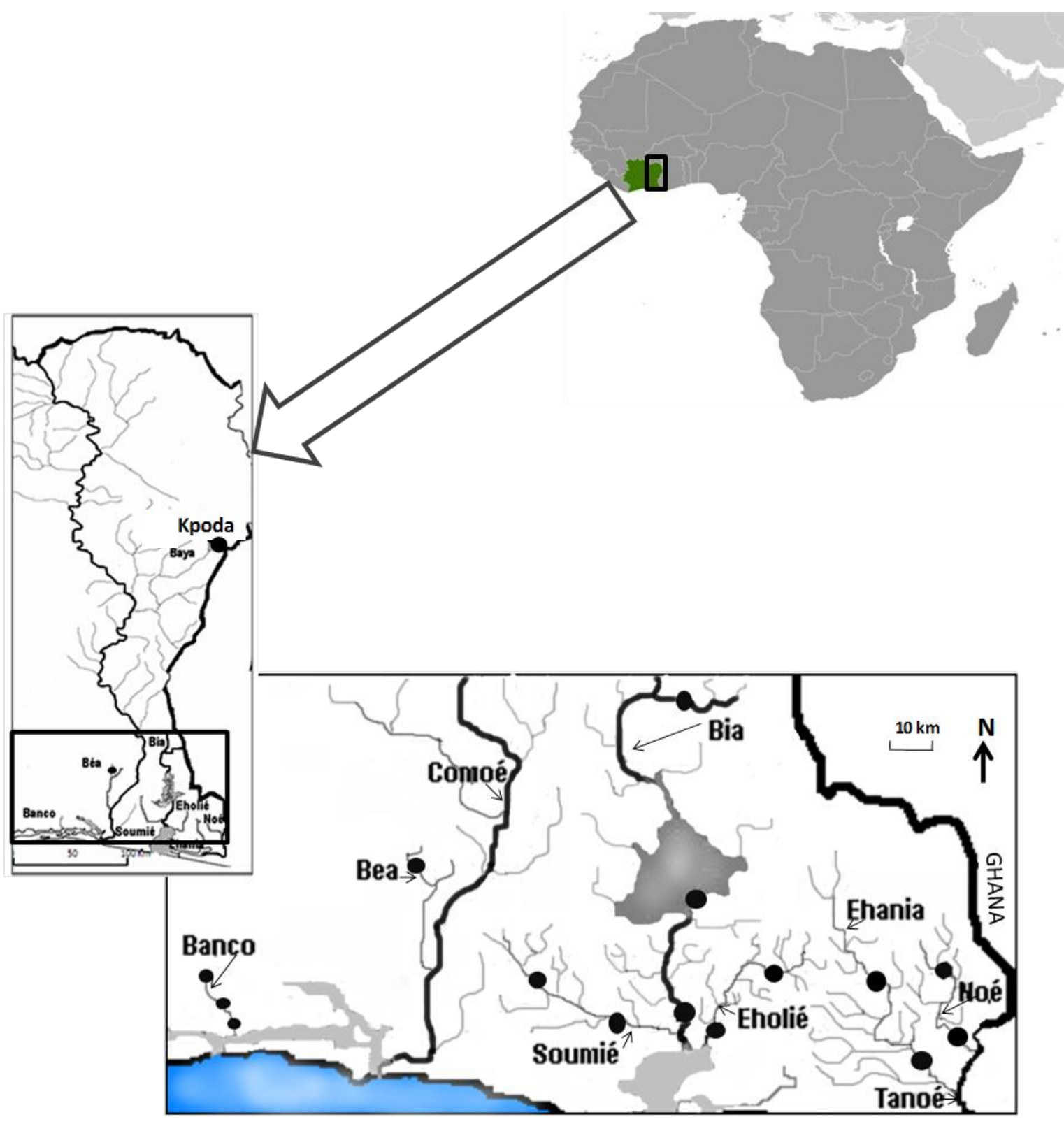

Figure 1. Location of sampling stations used for the current study. $\bullet=$ sampling stations.

\subsection{Data Analysis}

This procedure should be executed by a constant reference called Standard Weight (SW). The Standard Weight (SW) is the arithmetic mean of weights of stomach contents of specimens of a representative sample of the current study. Four points have been ascribed to the SW and then points have been ascribed to each stomach content (using integers) according to its proportional weight in relation to the SW. Points obtained for each gut content were then distributed to among the items in this stomach, in proportion to the volume each item occupies. The points ascribed to each food item found in the sample of stomachs were used to calculate the Volumetric Analysis Index according to the following formula: 


$$
V i=25 \times \frac{\sum i}{\mathrm{n}}
$$

where:

$\mathrm{V}_{\mathrm{i}}$ : Volumetric Analysis Index of the food item $i$ in the sample $\mathrm{i}$; $\sum \mathrm{i}$ : Sum of the ascribed points for the food item; $n$ : total number of stomachs with food in the sample.

The Items Importance or Preponderance Index indicates the relative importance a determined food category (item) plays in the fish's diet. It has been obtained separately for each food item by using the following formula:

$$
\mathrm{IPi}=\boldsymbol{F i} \times \boldsymbol{V i}
$$

where:

IPi: Importance Index of the food item $i$ in the sample; Fi: Occurrence Frequency of the item; Vi: Volumetric Analysis Index of the item.

The IP calculated for each item, has been expressed in percentage as for IRI (index of relative importance) in order to make comparisons between samples. Thus, IP has been calculated as follows:

$$
\% \mathrm{IPi}=100 \times \frac{I P i}{\sum_{i=1}^{n} I P i}
$$

Diet diversity was estimated using Levins' (1968) index of niche breadth (also called niche width or niche size) according to Marshall \& Elliot (1997):

$$
\mathrm{B}=\frac{1}{\sum_{i=1}^{n} V i^{2}}
$$

This index has been standardized in order to permit valuable comparisons between diets. Then the Levins Standardized Index according to Pedersen (1999) and Poslusziny et al. (2007):

$$
B_{\text {stan }}=\frac{B-1}{n-1}
$$

with $\mathrm{B}$ the Levins Index and $n$, the total number of prey items. Bstan ranges from 0 (diet restricted to a few number of prey) to 1(generalist diet) (Lorenzoni et al., 2007).

The degree of similarity between the feeding habits in the different hydrosystems are given by the Morisita (1959) index of similarity modified by Horn (1966). Volumetric analysis index was used to calculated similarity index according to the formulae of Horn (1966): 


$$
C_{j k}=\frac{2 \sum_{i=1}^{n}\left(V_{i j} \times V_{i k}\right)}{\sum_{i=1}^{n} V_{i j}{ }^{2}+\sum_{i=1}^{n} V_{i k}{ }^{2}}
$$

Where $C_{j k}$ is the Horn similarity index, $V_{i j}$ and $V_{i k}$ are proportions of item $i$ encountered respectively in diets of individuals groups $j$ and $k, n$ is the number of items common to both groups. The feeding habits are then compared by pair of hydrosystems. $C_{j k}$ varies from 0 when the feeding habits are completely distinct, to 1 when they are identical. Above 0.6 the similarity between feeding habits is considered significant.

The Costello graphical method (Costello, 1990), modified by Amundsen et al. (1996), was employed to look for general trends in feeding behavior and feeding strategy of Chromidotilapia guntheri in the studied hydrosystems.

Ontogenetic variation in prey preference was also assessed by means of "Focused Principal Component Analysis" (Falissard, 1999) as this test more carefully depicts than PCA correlations between independent variables and either size or weight.

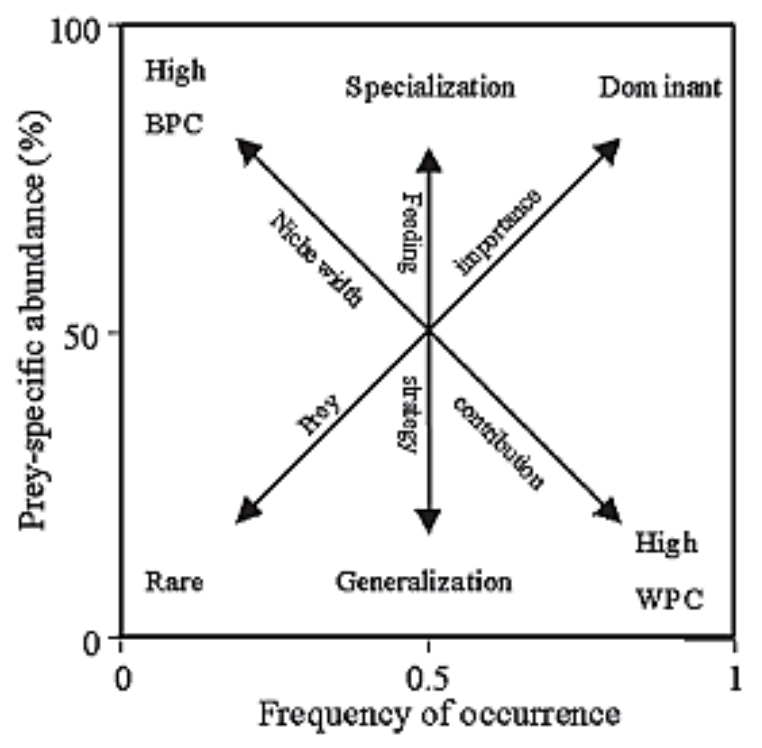

Figure 2. Modified Costello graph showing explanatory axes (modified from Amundsen et al., 1996) and its interpretation to indicate feeding strategy. (BPC = between-phenotype component; WPC = within-phenotype component)

\section{Results}

\subsection{Diet Composition}

Stomachs of 156 specimens of Chromidotilapia guntheri from five rivers, Banco, Soumié, Eholié, Ehania and Noé, a stream (Bea Rill) and from Kpoda Lake were analyzed. Fish size ranged from 50 to $140 \mathrm{~mm}$ SL. Size-frequency distribution was bimodal with modes at $75 \mathrm{~mm}$ and $115 \mathrm{~mm}$ (Figure 3). In most of the prospected hydrosystems, the most encountered items in gut contents of $C$. guntheri were plants debris and Insects pieces (Table 1). In addition to 
debris, mud constituted an important part of the gut contents. Indeed, plants debris were preponderant in guts of individuals from Ehania $(\mathrm{IP}=44.74 \%)$, Noé $(\mathrm{IP}=34.77 \%)$, Banco $(\mathrm{IP}=70.15 \%)$, Bea Rill $(\mathrm{IP}=37.10 \%)$ and Kpoda Lake (IP= 57.18\%). In Eholié River, Insects pieces were more abundant in $C$. guntheri diet. The formally identified animal preys were Gastropods, Bivalves, Oligochaetes, Copepods, Adult Insects, Insect larvae and Nymphs. To these items, were added sometimes an important proportion of sand, mud, fruits (pulp, shells and seeds), fish scales and fish eggs.

\subsection{Trophic Niche Width per Ecosystem and Similarity of Feeding Habits between Hydrosystems}

The Levins' (1968) index of niche breadth (Table 2) values are closer indicating that niches size in the studied hydrosystems were not significantly different. Nevertheless, Bea Stream $\left(B_{\text {stan }}=0.173\right)$ niche width was the largest and that of Noé river $\left(B_{\text {stan }}=0.132\right)$, the narrowest.

The feeding habits compared by pair of hydrosystems through Horn index (Table 2) showed an important similarity in prey eaten by fishes in rivers Ehania, Eholié, Soumié and Noé (all pairwise comparison Horn index > 0.6). However, items consumed in these rivers were different from those eaten in Kpoda Lake. Feeding habits in Bea Rill and Banco River and that in Kpoda Lake are similar (all pairwise comparison Horn indices > 0.8).

\subsection{Feeding Strategies}

The feeding strategy of Chromidotilapia. guntheri in each hydrosystem was determined from Amundsen's modified Costello Diagram (Figure 4).

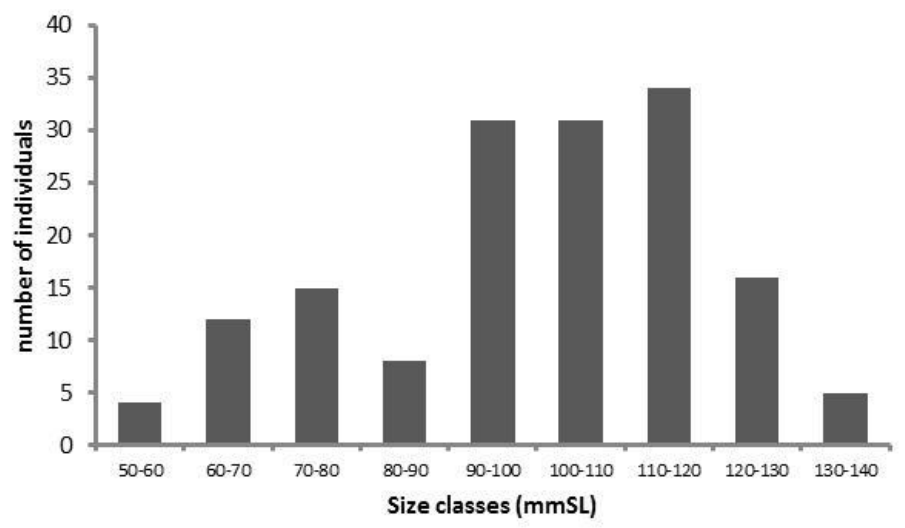

Figure 3. Size-frequency distribution of Chromidotilapia guntheri, collected in the South and East hydrosystems of Côte d'Ivoire. SL = Standard Length

As rivers Soumié, Eholié, Ehania and Noé are geographically close and C. guntheri has similar diets in these hydrosystems, the data for these rivers have been grouped into a single cluster. The diagram indicates that in these four rivers (Figure 4A), mud (IT4) is the most dominant item in stomach contents of this species and then, followed plants debris (IT2), Diptera larvae ( IT41) and fruits (IT5). The feeding strategy is generalist with a strong tendency for some individuals to specialize on adult insects of Ephemeridae (IT21) and Chironomidae (IT28) families, on nymphs of Coleoptera (IT37) and larvae of Libellulidae 
(IT46).

Table 1. Preponderance index (\% PI) of items in diet composition of Chromidotilapia guntheri from hydrosystems of South and East of Ivory Coast. LKPD = Kpoda Lake.

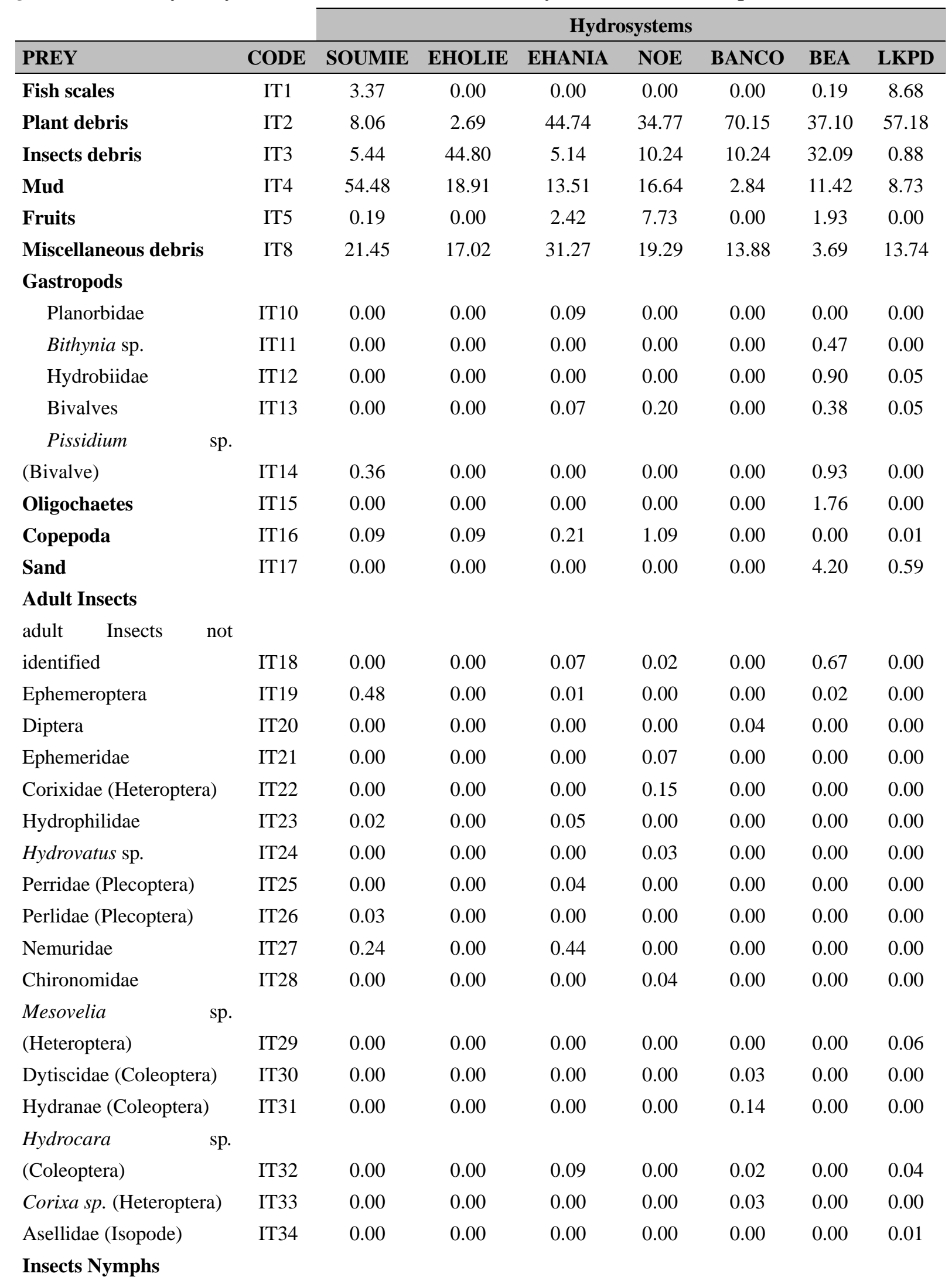




\begin{tabular}{lcccccccc}
\hline & & \multicolumn{7}{c}{ Hydrosystems } \\
\cline { 3 - 8 } PREY & CODE & SOUMIE & EHOLIE & EHANIA & NOE & BANCO & BEA & LKPD \\
\hline Nymphs not identified & IT35 & 0.00 & 0.00 & 0.00 & 0.00 & 0.00 & 0.00 & 0.03 \\
Nymphs & & & & & & & & \\
Chironomidae & IT36 & 0.16 & 0.00 & 0.00 & 0.00 & 0.00 & 0.00 & 0.15 \\
Nymphs of Coleoptera & IT37 & 0.00 & 16.49 & 0.00 & 0.00 & 0.00 & 0.00 & 0.12 \\
Nymphs of Leuctridae & IT38 & 0.00 & 0.00 & 0.04 & 0.00 & 0.00 & 0.00 & 0.00 \\
Nymphs de Diptera & IT39 & 0.00 & 0.00 & 0.00 & 0.00 & 0.00 & 0.19 & 1.46 \\
Larvae & & & & & & & & \\
Larvae not identified & IT40 & 1.92 & 0.00 & 0.24 & 0.00 & 0.00 & 0.00 & 0.00 \\
Larvae of Diptera* & IT41 & 3.65 & 0.00 & 1.47 & 9.38 & 0.02 & 0.00 & 1.35 \\
Larvae of Chironomidae* & IT42 & 0.01 & 0.00 & 0.01 & 0.00 & 1.36 & 1.81 & 3.87 \\
Larvae of Noterus sp. & IT43 & 0.00 & 0.00 & 0.02 & 0.00 & 0.00 & 0.06 & 0.00 \\
Larvae of Hyphydrus sp. & IT44 & 0.00 & 0.00 & 0.00 & 0.23 & 0.00 & 0.00 & 0.00 \\
Larvae of Ephemeroptera & IT45 & 0.06 & 0.00 & 0.00 & 0.03 & 0.00 & 0.89 & 0.39 \\
Larvae of Libellulidae & IT46 & 0.00 & 0.00 & 0.00 & 0.02 & 0.02 & 0.01 & 0.00 \\
Larvae of Trichoptera & IT47 & 0.00 & 0.00 & 0.08 & 0.00 & 0.00 & 0.00 & 0.00 \\
Larvae of Philopotamidae & IT48 & 0.00 & 0.00 & 0.00 & 0.02 & 0.00 & 0.00 & 0.15 \\
Larvae of Cordulegaster & & & & & & & & \\
sp. & IT49 & 0.00 & 0.00 & 0.00 & 0.02 & 0.00 & 0.06 & 0.00 \\
Larvae of Dryopidae & IT50 & 0.00 & 0.00 & 0.00 & 0.01 & 0.00 & 0.01 & 2.18 \\
Larvae of Chaoborus sp. & IT52 & 0.00 & 0.00 & 0.00 & 0.00 & 0.84 & 0.00 & 0.00 \\
Larvae of Plecoptera & IT53 & 0.00 & 0.00 & 0.00 & 0.00 & 0.00 & 0.08 & 0.00 \\
Larvae of Lepidoptera & IT54 & 0.00 & 0.00 & 0.00 & 0.00 & 0.00 & 0.25 & 0.00 \\
Larvae of Esolus sp. & IT55 & 0.00 & 0.00 & 0.00 & 0.00 & 0.00 & 0.07 & 0.05 \\
Larvae of Dytiscidae & IT56 & 0.00 & 0.00 & 0.00 & 0.00 & 0.16 & 0.83 & 0.25 \\
Larvae of Corixa sp. & IT57 & 0.00 & 0.00 & 0.00 & 0.00 & 0.00 & 0.01 & 0.00 \\
\hline
\end{tabular}

In the Banco River (Figure 4B), C. guntheri has adopted a generalist strategy focused on the consumption of insects and various debris with a strong tendency for opportunism on rare prey. However, plant debris (IT2) was the most abundant item in their diet. In Bea stream (Figure 4C), the feeding strategy is generalization on all prey. Here again plant debris were the most abundant consumed item. In Kpoda Lake (Figure 4D), although $C$. guntheri is a generalist, it has a strong propensity for opportunism, particularly on Coleoptera nymphs and Ephemeridae larvae. 
Table 2. Horn index and Levin's index (Bstan) showing respectively the similarity of feeding habits of Chromidotilapia guntheri between hydrosystems and the niche width by hydrosystem southeastern of Ivory Coast.

\begin{tabular}{llllllll}
\hline & Banco & Bea & $\begin{array}{l}\text { Kpoda } \\
\text { Lake }\end{array}$ & Soumié & Ehania & Eholié & Noé \\
\hline Banco & 1 & & & & & & \\
Bea & $0.884 *$ & 1 & & & & & \\
Kpoda Lake & $0.923 *$ & $0.823 *$ & 1 & & & & \\
Soumié & 0.321 & 0.411 & 0.422 & 1 & & & \\
Ehania & 0.568 & $0.812 *$ & 0.555 & $0.733 *$ & 1 & & \\
Eholié & 0.598 & $0.613 *$ & 0.336 & $0.884 *$ & $0.787 *$ & 1 & \\
Noé & 0.274 & 0.521 & 0.299 & $0.601 *$ & $0.685^{*}$ & $0.952 *$ & 1 \\
\hline Levin's index (Bstan) & $\mathbf{0 . 1 5 5}$ & $\mathbf{0 . 1 7 3}$ & $\mathbf{0 . 1 4 7}$ & $\mathbf{0 . 1 5 2}$ & $\mathbf{0 . 1 4 1}$ & $\mathbf{0 . 1 5 8}$ & $\mathbf{0 . 1 3 2}$ \\
\hline *significant similarity & & & & & & &
\end{tabular}

\subsection{Changes in Feeding Habits with Size}

As the main prey varied less according to the surveyed hydrosystems, this analysis took into account the grouped data (figure 5). Animal preys, mainly insects, are grouped according to their stages of development (larvae, nymphs and adults).

Plants debris were widely consumed by Chromidotilapia guntheri in most of the size classes, particularly in the $[70-80 \mathrm{~mm}]$ and $[120-130 \mathrm{~mm}]$ classes where their IP exceeded $50 \%$. In addition to plant debris, insect debris, miscellaneous debris, mud and insect larvae have been found in the stomachs of individuals of all sizes. Adult insects were more abundant in the diet of larger individuals (class [130-140mm]). Gasteropods were observed only in the first three size classes (from 50 to $80 \mathrm{~mm}$ ), that correspond to juveniles size (size $<85 \mathrm{~mm}$ ).

The Focused Principal Component Analysis (FPCA) based on groups of items with a focus on the size of $C$. guntheri (Figure 6) indicated that, apart from ingestion of gastropods, oligochaetes and sand, the consumption of the other items is independent of the fish size. Indeed, only sand and gastropods are significantly correlated with the standard length of individuals. Their ingestion decreases significantly with fish size (negative correlation). In contrast, the consumption of miscellaneous debris, adult insects, insect larvae and mud does not increase significantly with fish size. On the other hand, miscellaneous debris, insect debris, adult insects, insect larvae and gastropods have been found frequently together in the same stomachs.

\section{Discussion}

The analysis of the stomach contents of $C$. guntheri in the studied hydrosystems reveals similar preferential preys in these habitats, although their proportions differ slightly from one site to another. In fact, this species feeds preferentially on plant and insect debris. Secondarily, it consumes insects of all ages (larvae, nymphs and adults). Fruits (hulls, pulps, seeds) are also an important part of food consumed secondarily by $C$. guntheri. According to the composition of the diet of $C$. guntheri in the different habitats, we can say that this species is 


\section{Macrothink

an omnivore with a detritivorous tendency. The large occurence of insect debris in the stomach contents of $C$. guntheri could probably result from insects consumed whole but found partially digested. The significant presence of mud (which may be due to swallowing of benthos prey), plant debris, larvae, nymphs and adult insects in this species diet indicates that this species feeds on available prey from water surface to the benthos. These results corroborate those of Whitehead (1969) who indicated that C. guntheri fed on plants and zoobenthos in Volta Lake.

In terms of food strategy, results showed that this species practices a generalist strategy on animal and plant debris in the studied habitats. However, some individuals display specialization intentions on fruits and insects as Diptera, Coleoptera and Ephemeroptera at different stages of metamorphosis (larvae, nymphs and adults). Such a strategy (generalist), according to La Mesa et al. (2008), limits intraspecific competition on available food resources. According to Lévêque (2006), in small rivers, allochthonous contributions (fallouts of leaves or terrestrial insects for example) that constitute the base of the trophic web. Composition and extent of trophic niche of $C$. guntheri varied less from one habitat to another. Our results also confirmed the observations of Lauzanne (1988) who indicated that the feeding habit of African fish species is substantially identical over its entire area of distribution. The current study showed that Bea Rill that is a stream in the sampling area would provide a greater diversity of prey to $C$. guntheri than the other rivers relatively larger. Indeed, rills, with almost fully enclosed canopy, abundant aquatic vegetation and immersed wood, appeared to be more suitable for feeding of $C$. guntheri as this species is fond of plant debris, insects and other debris.
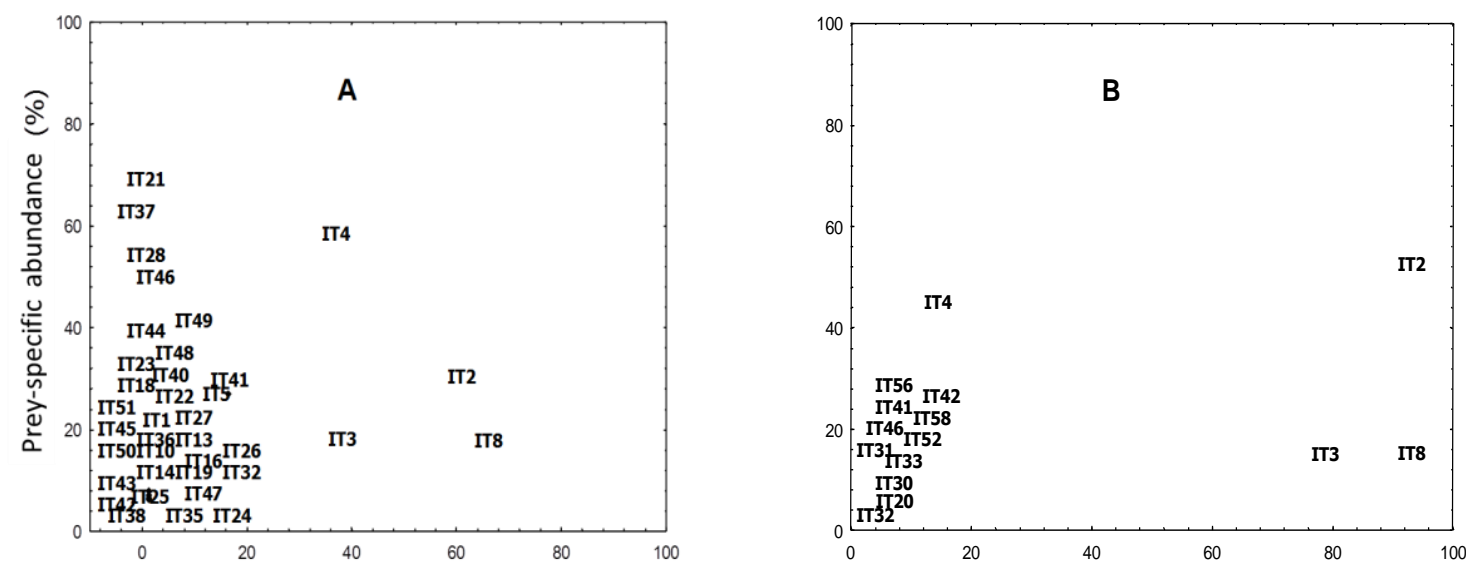

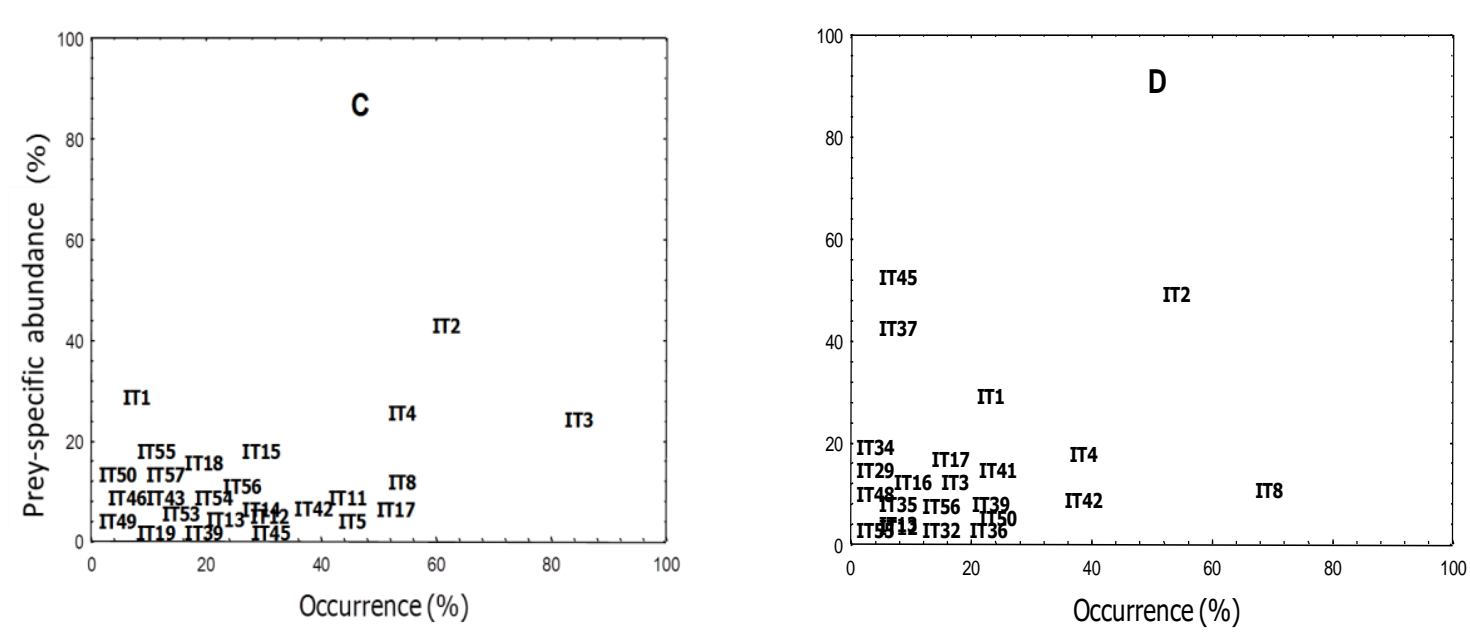

Figure 4. Costello diagrams (Amundsen et al., 1996) of Chromidotilapia guntheri diet by hydrosystem in south and east of Ivory Coast. A= four rivers Ehania, Eholié, Soumié and Noé grouped; $\mathrm{B}=$ Banco river; $\mathrm{C}=$ Bea stream; $\mathrm{D}=$ Kpoda Lake; $\mathrm{IT}=$ item.

These results are in accordance with those of Rolla et al. (2009) who indicated that the fish fauna of small streams is dominated by fish with a generalist diet (omnivorous and insectivorous).

The focused principal component analysis (FPCA) indicates that juveniles and adults of $C$. guntheri consume substantially the same types of prey with varying amounts depending on the size of the fish. However, fishes show a slight tendency when growing to eat adult insects, insect larvae and various debris. There is also a significant decrease in the proportions of gastropods and oligochaetes ingested when growing. An explanation is given in part by Singer (1985) who reported that changes in the food composition of a species when changing in size would be an adaptive functional response to changes in metabolic needs.

\section{Acknowledgements}

This study was funded by a partnership between FEM/ONG (Fonds pour 1'Environnement Mondial/NGO) and WSA (Water and Sanitation for Africa) directed by Prof. Theophile GNAGNE. We are grateful to all the members of the Laboratory of Environment and Aquatic Biology of Nangui Abrogoua University for their valuable contribution to the achievement of this study. 


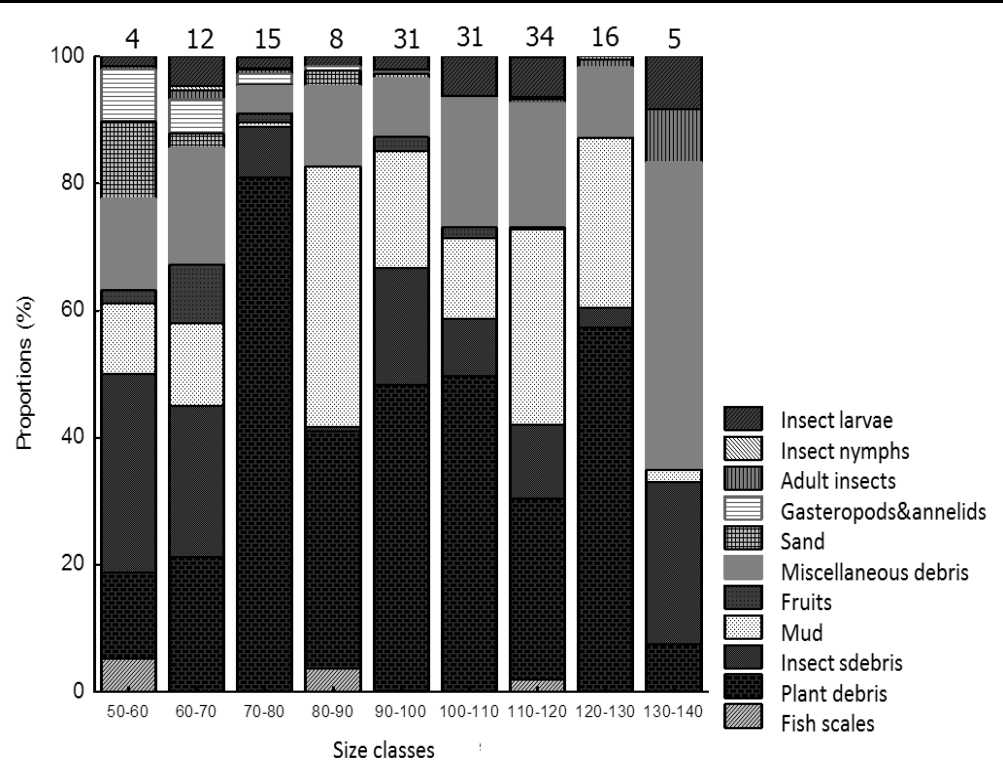

Figure 5. Variation in preponderance of diet components according to size classes of Chromidotilapia guntheri. The number on each column correspond to the number of stomach contents observed in the corresponding size class.

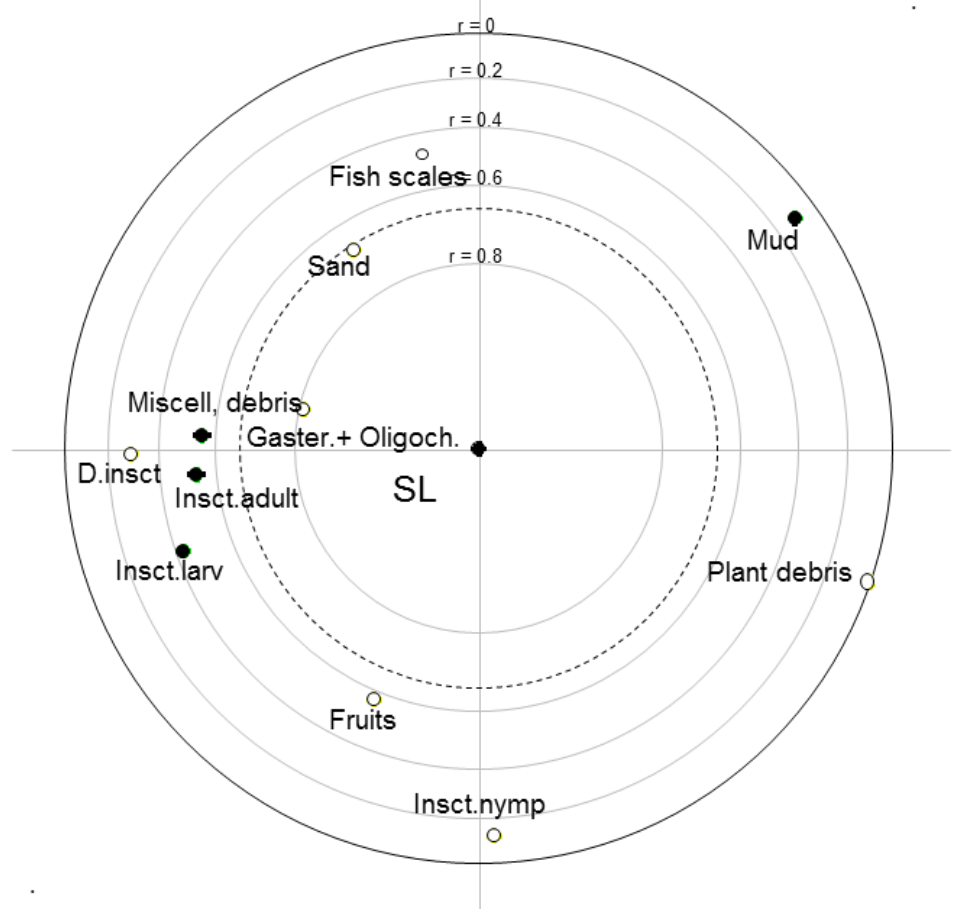

Figure 6. Graph depicting the Focused Principal Component Analysis (FPCA) based on the size of Chromidotilapia guntheri as a dependent variable and the prey component of the diet as independent variables. Empty dots correspond to items negatively correlated with fish size; bold dots indicate items positively correlated with fish size. Points inside the dotted circle represent items that are significantly correlated $(p<0.05)$ with fish size. Grouped dots are prey found frequently together a same stomach content, whilst uncorrelated clusters make right angles at the circle origin. $\mathrm{D}=$ Debris; nymp = nymph; $\mathrm{SL}=$ standard length; Insct = insects; Gaster = Gastropods; Larv = larvae; Oligoch = Oligochaetes. Miscell.= Miscellaneous. 


\section{References}

Amundsen, P. A., Gabler, H. M., \& Staldvik, F. J. (1996). A new approach to graphical analysis of feeding strategy from stomach contents data-modification of the Costello (1990) method. Journal of Fish Biology, 48(4), 607-614.

Arim, M., Marquet, P. A., \& Jaksic, F. M. (2007). On the relationship between productivity and food chain length at different ecological levels. American Naturalist, 169, 62-72. https://doi.org/10.1086/510210.

Berryman, A. A. (1999). Principles of populations' dynamics and their application. Cheltenham, Stanley Thornes.

Boussou, C. K., Edia, O. E., Konan, F. K., Ouattara, M., Ouattara, A., \& Gourène, G. (2010b). Reproductive biology of Chromidotilapia guntheri (Sauvage, 1882) (Perciformes: Cichlidae) in four coastal rivers (Ehania, Noé, Soumié and Eholié) of Côte d'Ivoire in West Africa. Knowledge and Management of Aquatic Ecosystems, 396(03), 16. https://doi.org/10.1051/kmae/2010013

Boussou, C. K., Konan, F. K., Edia, O. E., Ouattara, M., Bony, Y. K., Ouattara, A., \& Gourène, G. (2010a). Morphometric analysis of populations of Chromidotilapia guntheri (Sauvage, 1882) (Perciformes: Cichlidae) in four coastal rivers of Côte d'Ivoire (West Africa). Pan-American Journal of Aquatic Sciences, 5(3), 387- 400.

Brown, J. H., Gillooly, J. F., Allen, A. P.,. Savage, V. M., \& West. G. B. (2004). Toward a metabolic theory of ecology. Ecology, 85, 1771-1789. https://doi.org/10.1890/03-9000

Costello, M. J. (1990). Predator feeding strategy and prey importance: a new graphical analysis. Journal of Fish Biology, 36, 261-263. https://doi.org/10.1111/j.1095-8649.1990.tb05601.x

Da Costa, S. K., Gourène, G., Tito De Morais, L,. \& Thys van den Audenaerde, D. F. E. (2000). Caractérisation des peuplements ichtyologiques de deux fleuves côtiers ouestafricains soumis à des aménagements hydro-agricoles et hydroélectriques. Vie et Milieu, 50(2), 65-77.

Daget, J., \& Iltis, A. (1965). Poissons de Côte d'Ivoire (eaux douces et saumâtres),74. Édition IFAN (Institut Français de l'Afrique Noire). Dakar, Sénégal.

Déjoux, C., Elouard, J. M., Forge, P., \& Maslin, J. L. (1981). Catalogue iconographique des insectes aquatiques de Côte d'Ivoire, 42. ORSTOM.

Falissard, B. (1999). Focused Principal Component Analysis: looking at a correlation matrix with a particular interest in a given variable. Journal of Computational and Graphical Statistics, 8, 906-912.

Gourène, G., Teugels, G. G., Hugueny, B., \& Thys van ven Audenaerde, D. F. E. (1999). Evaluation et conservation de la diversité ichtyologique d'un bassin ouest-africain après la construction d'un barrage. Cybium, 23(2), 147-160.

Horn, H. S. (1966). Measurement of overlap in comparative ecological studies. American Naturalist, 100, 419-424. https://doi.org/10.1086/282436 


\section{Ml Macrothink}

Aquatic Science and Technology

ISSN 2168-9148

2018, Vol. 6, No. 1

Konan, F. K., Leprieur, F., Ouattara, A., Brosse, S., Grenouillet, G., Gourène, G., Winterton, P., \& Lek, S. (2006). Spatio-temporal patterns of fish assemblages in coastal West African rivers: a self-organizing map approach. Aquatic Living Resources, 19, 361-370. https://doi.org/10.1051/alr:2007006

La Mesa, M., Borme, D., Tirelli, V., Poi, E. D., Legovini, S., \& Fonda Umani, S. (2008). Feeding ecology of the transparent goby Aphia minuta (Pisces: Gobiidae) in the northwestern Adriatic Sea. Scientia Marina, 72(1), 99-108. https://doi.org/10.3989/scimar.2008.72n199

Lauzanne, L. (1988). Les habitudes alimentaires des poissons d'eaux douces africains. In C. Lévêque, M. N. Bruton \& G. W. Ssentongo (Eds.), Biologie et Ecologie des poissons d'eaux douces africains (ORSTOM, 221-242), Paris : ORSTOM.

Lévêque, C. (2006). Réponses aux conditions extrêmes. In C. Lévêque \& D. Paugy (Eds.), Les poissons des eaux continentales africaines. Diversité, Ecologie, Utilisation par l'homme (IRD, 217-224) Paris : IRD.

Lévêque, C., Paugy, D., \& Teugels, G.G. (1991). Annotated check-list of the freshwater fishes of the Nilo-sudan river basins, in Africa. Revue d'Hydrobiologie Tropicale, 24, 131-154.

Levins, R. (1968). Evolution in changing environments: some theorical exploitations. Princeton University Press.

Lima-Junior, S. E., \& Goitein, R. (2001). A new method for the analysis of fish stomach contents. Maringá, Acta Scientiarum, 23(2), 421-424.

Lorenzoni, M., Carosi, A., Pedicillo, G., \& Trusso, A. (2007). A comparative study on the feeding competition of the european perch Perca fluviatilis L. and the ruffe Gymnocephalus cernuus (L.) in lake Piediluco (Umbria, Italy). BFPP/Bulletin Français de Pêche et de Pisciculture, 387, 35-57. https://doi.org/10.1051/kmae:2007016

Marshall, S., \& Elliot M. (1997). A comparison of univariate and multivariate numerical and graphical techniques for determining inter- and intraspecifc feeding relationships in estuarine fish. Journal of Fish Biology, 51, 526-545. https://doi.org/10.1111/j.1095-8649.1997.tb01510.x

McNAB, B. K. (2002). The physiological ecology of vertebrates. Ithaca, Cornell University Press.

Morisita, M. (1959). Measuring of interspecific association and similarity between communities. Memoirs of the Faculty of Science Kyushu University Series E, 3, 65-80.

Paugy, D., Lévêque, C., \& Teugels, G. G. (2003). Poissons d'eaux douces et saumâtres de l'Afrique de l'Ouest. Institut de recherche et de développement, Paris, France. Muséum national d'histoire naturelle, Paris, France et Musée royal de l'Afrique Central, Tervuren, Belgique.

Paugy, D., Traoré, K., \& Diouf, P. S. (1994). Faune ichtyologique des eaux douces d'Afrique de l'Ouest. In G.G. Teugels, J. F. Guégan et J. J. Albaret (Eds.), Diversité des poissons des eaux douces et saumâtres d'Afrique (Ann. Mus. R. Afr. Centr., 177 pp, 35-66), Tervuren, 
Belgique

Pedersen, J. (1999). Diet comparison between pelagic and demersal whiting in the North Sea. Journal of Fish Biology, 55, 1096-1113. https://doi.org/10.1111/j.1095-8649.1999.tb00744.x

Poslusziny, M., Pilot, M., Goszczynski, J., \& Gralak, B. (2007). Diet of sympatric pine marten Martes martes and stone marten Martes foina idenfied by genotyping of DNA from faeces. Annales Zoologici Fennici, 44, 269-284.

Rolla, A. P. P. R., Esteves, K. E., \& Ávila-da-Silva, A. O. (2009). Feeding ecology of a stream fish assemblage in an Atlantic Forest remnant (Serra do Japi, SP, Brazil). Neotropical Ichthyology, 7(1), 65-76. https://doi.org/10.1590/S1679-62252009000100009

Singer, M. (1985). Food habits of juvenile rockfishes (Sebastes) in a Central California kelp forest. Fishery Bulletin of U.S, 83, 531-541.

Tachet, H., Richaux, P., Bournaud, M., \& Usseglio-Polatera, P. (2003). Invertébrés d'eau douce : Systématique, biologie, et écologie. CNRS Editions, Paris,

Teugels, G. G., Lévêque, C., Paugy, D., \& Traoré, K. (1988). État des connaissances sur la faune ichtyologique des bassins côtiers de Côte d'Ivoire et de l'ouest du Ghana. Revue d'Hydrobiologie Tropicale, 21(3), 221-237.

Thébault, E., \& Loreau, M. (2006). The relationship between biodiversity and ecosystem functioning in food webs. Ecological Research, 21, 17-25. https://doi.org/10.1007/s11284-005-0127-9

Vivien, J. (1991). Faune du Cameroun - Guide des mammifères et des poissons, GICA

Ward, A. J. W., Hart, P. J. B., \& Krauseb, J. (2004). The effects of habitat- and diet-based cues on association preferences in three spined sticklebacks. Behavioral Ecology, 15(6), 925-929. https://doi.org/10.1093/beheco/arh097

Whitehead, V. (1969). Investigations into the food habits of some juvenile fish in the Volta Lake during the period from October 1969 to March 1969 with some notes on distribution and abundance. University of Ghana, Volta Research Project Tech. Rep. X30.

Winemiller, K. O. (1991). Ecomorphological diversification of freshwater fish assemblages from five biotic regions. Ecological Monographs, 61, 343-365. https://doi.org/10.2307/2937046

Wootton, R. J. (1990). Ecology of Teleost Fishes. Chapman \& Hall, London.

\section{Copyrights}

Copyright for this article is retained by the author(s), with first publication rights granted to the journal.

This is an open-access article distributed under the terms and conditions of the Creative Commons Attribution license (http://creativecommons.org/licenses/by/4.0/) 